\title{
The strengthening of company competitiveness during the crisis period
}

\begin{abstract}
The current financial crisis should be considered as an opportunity for preparation for open competition on the EU market. This text describes particular activities as regards state administration reforms as well as the increase in the capacity of domestic enterprises in order to prepare them for the post-crisis period. The first part of the article sets down an overview of legislative reform as a measure of state intervention in the period of preparation for accession to the EU, while the second part presents a measure of the activity of support programmes to enterprises with the aim of preparing them for the period after the crisis. The article shows the need for investment in the improvement of business mechanisms and the deployment of best business practices which are proven to be successful in creating a business-enabling environment and introducing a better standard of living.
\end{abstract}

Keywords: competitiveness, crisis, investments, reform

Introduction

The global financial crisis did not present the collapse of capitalism as did the Great Depression, nor did it cause a re-strengthening of capitalism as in 1989, but this Great Recession will leave permanent marks: a more stable world financial system with fewer 'bubbles' and stricter regulations and supervision, but with a lower world growth rate in the following five-seven years.

There are no doubts now that Serbia is in the group of countries which have been significantly hit by the world economic crisis. Moreover, it has recorded the highest fall in foreign trade, industrial production and GDP in the region. ${ }^{1}$ Therefore, the issue of competitiveness in Serbia is a particularly significant one, especially during the period of the crisis. Thus, one needs to deal with this problem in an appropriate manner in order to minimise the effects of the crisis.

The current state of the Serbian economy

In the crisis period, the level of investment has significantly decreased at a global level: investments are smaller and investors are choosing locations a lot more carefully. It has, therefore, become more difficult to source funds for investment projects. Serbia as an investment destination, in an environment of fierce competition from other countries, will have to try harder to attract investors.

1 www.ekonomija.org 
In early 2010, government ministries accepted an obligation to implement recommendations for improving Serbia's competitiveness and a government action plan was drafted for this purpose. However, we cannot be satisfied with the results that have been achieved thus far. According to the latest World Economic Forum, in September 2010, Serbia has dropped to $96^{\text {th }}$ place of the 139 countries. $^{2}$ Of the countries with we used to share a common destiny, Montenegro has made the biggest progress, taking 49th place. It is interesting to see that, of 111 indicators estimating the level of competitiveness, in $78(70 \%)$, Serbia has lost ratings and is relatively lagging. The worst results were achieved in the segment of the development of institutions and of infrastructure, especially in the administrative and the logistical. The degree to which Serbia is lagging in these two areas, which are fundamental to competitiveness, is dramatically reflected in the whole national economy and the living standards of citizens. ${ }^{3}$

Political problems are also hampering us due to an insufficient effort at reform. We need to make a serious effort at implementing the recommended reforms with the goal of creating a more successful Serbia, so as to make real progress up the list. A feasibility study, association agreement and the potential achievement of the status of EU membership candidate has a significant positive impact and gives an incentive to economic reforms, thus making Serbia increasingly attractive to investors. Based on the example of countries which have recently joined the EU, we can see that there is a direct relationship between attaining the status of official candidate and increased investment in these countries. Similar is expected in Serbia, simply because this status gives investors a feeling of security and a suitable business climate. When investors are considering locations in which to place their funds, they are likely to look for countries which are politically stable. Therefore, every detour from the road of joining the EU leads to a loss of foreign investment and a negative perception of our country as a good destination for business. Official political decisions, primarily the UN Resolution of 10 September 2010 , give a positive signal of the region's stabilisation and send the message to investors that Serbia remains committed to joining the EU.

After a period of a significant fall, during 2008, late 2009 and in 2010, trade flows have been gaining momentum. Exports recovered by $18 \%$ annually in the first half of 2010, while imports have risen by only $4 \%$ (see Figure 1). Unfortunately, the depreciation of the dinar has had a great influence on this flow: the real increase in exports was not caused by an increase in the real competitiveness of our companies.

Non-customs barriers in trade with CEFTA countries, the monopolistic position of public enterprises and insufficient financial stimuli to exporting companies are just some of the problems that business leaders in Serbia have reported. Direct results that the business community expects from the government, which would have an impact on competitiveness, are:

- making changes to administrative procedures (a guillotine of regulation)

- stimulating the issue of construction permits

2 Global Competitiveness Index 2010-2011 rankings and 2009-2010 comparisons www.weforum.org.

3 Savić, Nebojša (2010) 'Kako unaprediti konkurentnost Srbije. Problematične institucije i infrastruktura' Ekonom:east 549, 27 November 2010. 
- issuing government guarantees to business to take loans instead of subsidising interest rates to banks

- addressing the absence of institutions for economic support which could resolve business problems.

Figure 1 - Export and import flows of Serbia

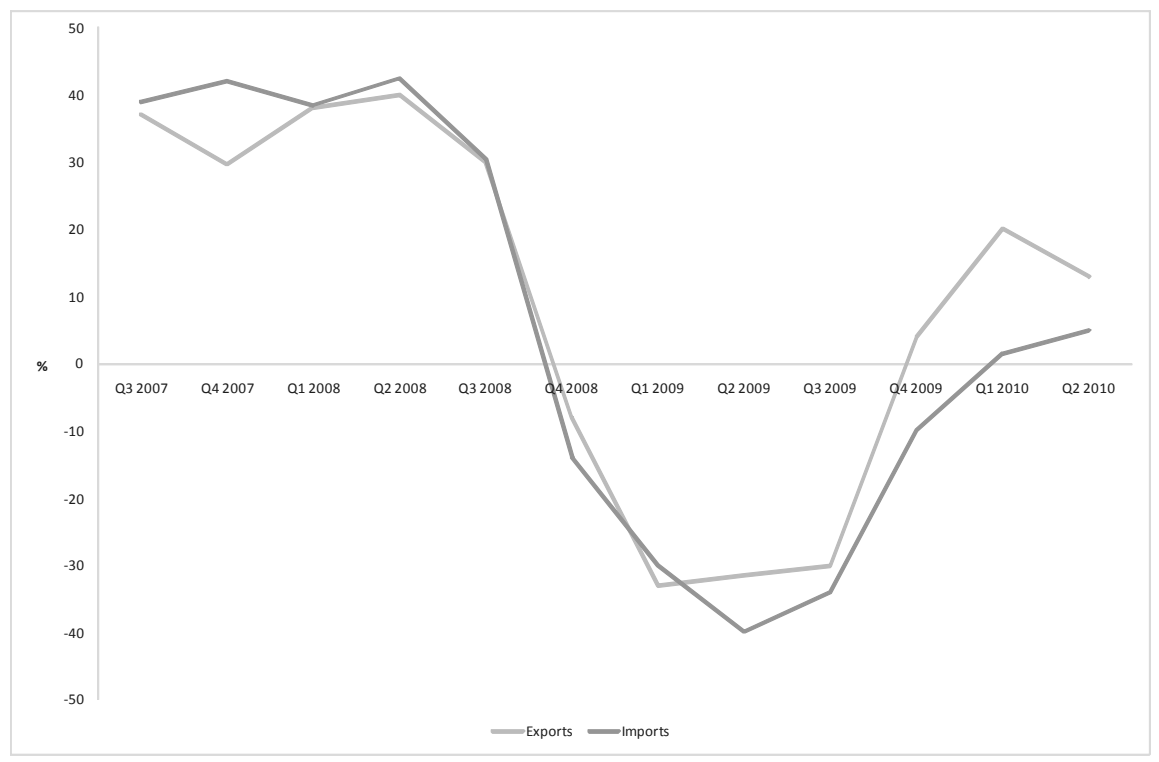

Source: Hardouvelis, Gikas A (2010)

An important segment in which some unfortunate results have been achieved is the question of the marketability of the business environment. Serbia operates at the very bottom of the segment of the functioning of the market, i.e. in $138^{\text {th }}$ and $137^{\text {th }}$ places respectively concerning its market domination and anti-monopoly policies. Moreover, in terms of the intensity of local competition and in the buyer concept, we are in only $131^{\text {st }}$ place. We have a too strong domination of players making offers and neglected customers in demand; without demanding customers there is no quality domestic offer. ${ }^{4}$

The government should be careful not to let potential investors use their search for the lowest wages and the meekest regulations in the most exploitative way, i.e. where competition is based on who will work for less money? Or on who will agree to halve working hours? (Vujović et al, 2010). Serbia needs to reach out to real investors who will create value in our country.

4 www.naled-serbia.org. 
New business climate (exemptions for entrepreneurs)

Entrepreneurs and business leaders are struggling to find a way out of the administrative labyrinth, instead of doing their jobs and creating products and services that they can offer at the best available price. On the contrary, investors will, on seeing how exhaustive is the process of issuing documents, go elsewhere. The government has tried to solve this long-lasting problem and has taken an obligation to simplify procedures via a Universal Reform of Regulations, implemented by an eponymous named unit within the Ministry of Economy and Regional Development. Nevertheless, the problem that is being constantly postponed is the restructuring of public enterprises, i.e. those which are partly responsible for the complex procedures and the intertwining of these two problems.

Beside certain good examples, such as establishing a single-counter system for the registration of legal entities within the Agency for Economic Registration and acquiring a permit to trade, most of the proposals for solving problems set out in the Grey Book (NALED) have still not been solved. New proposals and suggestions are still mostly related to procedures for the hiring and firing of employees and procedures for paying taxes and insurance. In such terms, the recommendation to government agencies is simply to deal with this issue. Procedures are perceived of as irrational and with too many steps and documents that need to be completed and submitted to different agencies. $^{5}$

The current state of reform is as follows:

- the deadline for realising the Comprehensive Regulatory Reform (CRR) expired on 30 June 2010

- the CRR process had started on February 2009 with the purpose of eliminating and changing obsolete or inefficient policies and procedures burdening the Serbian economy

- out of 214 recommendations for improving the regulatory framework adopted by the Serbian government, only 31 have been implemented so far, based on publicly available data

- so far, only ten out of 76 Grey Book recommendations for reducing bureaucratic procedures have been implemented, or partly implemented.

\section{Change proposals}

The visit of the ambassadors of nine of the most developed countries of the world, the OSCE and Deputy Prime Minister and Minister of the Economy, Mlađan Dinkić, to the region of south-western Serbia in order to hold a roundtable with entrepreneurs has brought out a couple of problems and solutions to consider if we are to improve the current conditions:

- 1st problem: lack of management skills in companies remains a key impediment to the development of industry

5 www.naled-serbia.org. 
- proposed actions: government and donors should co-ordinate their efforts to develop business and management skills among small- and medium-sized enterprises and to improve existing marketing, branding and sales techniques

- as a long-term initiative, improve the education system and match education profiles to industry's requirements for human resources

- 2nd problem: reform challenges - companies need to undertake extensive modernisation to meet and maintain EU standards due to the planned opening of the Serbian market

- proposed actions: there are a number of suggestions here, including: organising training programmes to introduce the international certifications needed for export; supporting the development of regional and national level association(s); and initiating republic-level incentive mechanisms for systematic support for regionally-specific sectors of industry

- 3rd problem: debts and financial challenges - the high existing debt burdens of most local firms make the purchase of modern production machinery very difficult. Financial support mechanisms and affordable banking products for small and micro enterprises do not exist

- proposed actions: the government should establish new institutions in the field of financial support, like micro finance organisations and non-banking mechanisms. The existing bank offer needs to be improved, with affordable banking products encompassing easier access to loans and other micro financial support mechanisms for modernising production, supporting exports and entering new markets

- 4th problem: the Republic of Serbia has no well-developed support mechanisms for export-oriented businesses

- proposed actions: introduce a financial incentive-based method to support exports, similar to incentives for foreign investors

- 5th problem: issues of financial discipline - the payment period for stock delivered to buyers is too long (larger chains are paying some 3-6 months after delivery)

- proposed actions: improve financial discipline at the level of the republic and introduce mechanisms for a more efficient payment procedure

- $6^{\text {th }}$ problem: the illegal import of low cost/low quality products

- proposed actions: the Republic of Serbia should introduce legislation that will launch and apply quality standards for imports.

We can see that one of the biggest problems in strengthening the competitiveness of our companies is the lack of quality staff. Without reforms in education it is impossible to address the structural problems: to create a competitive economy; and to decrease the rate of unemployment. ${ }^{6}$ It is necessary to follow world trends and direct future generations to educate themselves in profiles which enable their rapid employment in competitive and fast-growing economies. In the long-term, it is necessary to have a working and educated generation which creates value in Serbia, not to have

6 Jakopin, Edvard and Jurij Bajec (2009) 'Challenges of Industrial Development of Serbia' Panoeconomicus 4: 507-525 at p. 522. 
semi-finished products and raw materials and export them at low value. Therefore, a reform of the education system is necessary.

The significance of the continuous training and cost that this requires can best be seen in the example of other countries. According to analysis, companies in the US spend almost $\$ 60 \mathrm{bn}$ on training programmes and the review of skills. The internationalisation of business comprehends new skills, while companies wanting to function globally are forced to improve their work constantly. ${ }^{7}$

It is important to point out the legislative activity which is taking place as regards the development of a quality infrastructure and the support programmes for implementing quality standards which significantly improve the competitiveness of our companies. With a new law on standardisation coming into force, the conditions for the faster and more efficient adoption of European standards have been secured. Thus, the premises have been created for Serbia's full membership of the International Organization for Standardization (ISO) and other European standardisation organisations. The new law abolishes the application of over 8000 standards, fulfilling one of the major requirements of the World Trade Organization related to the voluntary application of standards. The result of this activity has been that only $6 \%$ of the total number of obligatory standards which have been applied up to now have been transferred into technical regulations, while the others have become voluntary.

A new law on accreditation is being passed with the goal of conforming with the rules of agreement on technical obstacles to trade and with the laws of the EU, as well as with the requirements of the standards of accreditation agencies which accredit bodies for compliance evaluation.

\section{Competitiveness-strengthening support programmes}

The government of the Republic of Serbia, through its governmental agencies, is putting aside a large amount of funds every year to support companies, primarily in the field of improving labour and strengthening competitiveness. The example of the National Agency for Regional Development can be shown to be a positive one; its approved funds for 2010 have been disbursed as follows: most of the approved applications are related to conforming business with quality standard requirements $(72.5 \%)$; then to business improvement projects $(22.2 \%)$; while, in a relatively limited scope are programmes in education $(3.4 \%)$ and work protection $(1.9 \%){ }^{8}$

Many of the foreign beneficiary programmes, funded by the EU delegation to Serbia and USAID, are co-operating with prosperous small- and medium-sized enterprises in the agriculture, industry and services sectors to increase productivity, improve quality and expand markets. Programme support is directed to exchange of experiences; examples of good business practice; workforce development; better access to markets; meeting international standards; and introducing new technologies. The development of a strong and competitive business environment offers the best prospects for longterm, sustainable economic development and a higher employment rate.

7 Đuričin, Dragan N, Stevo V. Janošević and Đorđe M. Kaličanin (2010) Menadžment i strategija Ekonomski fakultet u Beogradu: Beograd, at p. 476.

8 Program podrske razvoju konkurentnosti MSPP u 2010. godini. www.nar.gov.rs. 
There is a number of current programmes which are greatly contributing to the general economic development of Serbia.

\section{SECEP - Support to Enterprise Competitiveness and Export Promotion ${ }^{9}$}

This project seeks to improve the competitiveness of Serbian SMEs through three closely interlinked, but distinct, components: cluster development; supply chain development; and internationalisation - promoting Serbian SMEs and developing their ability to export. SECEP's overall objective is to support the development of international competitiveness and the export performance of SMEs. SECEP, which is financed by the European Union, is also supported by the Ministry for Economy and Regional Development; the Agency for Small and Medium Enterprises; the Serbian Chamber of Commerce; and the Serbia Investment and Export Promotion Agency, SIEPA.

\section{PPES: Preparedness, Planning and Economic Security ${ }^{10}$}

This programme is financed by USAID and works with the economy, government, and civil society in order to engage all relevant stakeholders in the process of private sector and workforce development. The programme's business development strategy involves the provision of sector-specific technical assistance to promising businesses with the capacity to expand into new markets and to gain market share. The programme takes a sectoral approach to business-level assistance and focuses geographically on south and south-west Serbia. Businesses operating in the following sectors are considered for assistance:
- apparel
- dairy
- food processing
- light manufacturing.

The business development activities supported by the programme include: supporting trade show attendance and study tour participation to ensure exposure to best practices and new technology; providing training in business skills, marketing, product design and sales; assisting with the acquisition of international quality standards; introducing companies to buyers through buyer visits; creating market linkages at trade shows; and assisting firms to access sources of finance.

\section{Agribusiness project ${ }^{11}$}

This five-year, \$24m economic development project provides assistance to Serbian agriculture and agribusiness with the aim of increasing agricultural sales and exports by Serbian firms and creating new employment in this sector. Project components include:

- increasing the competitiveness and efficiency of Serbian agribusiness enterprises right along the value chain in six high-potential agricultural sub-sectors: tree fruits; 
berry fruits; vegetables; mushrooms; herbs and spices; dairy products; and livestock.

- creating a positive enabling environment, which includes favourable legislation and policies, as well as the effective provision of essential agribusiness extension services, such as market information; annual agricultural production estimates; animal and plant health and food safety information; and regulatory oversight, such as licensing, labelling standards, product certification, etc.

\section{Competitiveness Project ${ }^{12}$}

This is a four-year, $\$ 14.7 \mathrm{~m}$ initiative launched in October 2007 and financed by USAID. The aim of the project is to promote economic growth by substantially increasing the competitiveness of Serbian SMEs in leading sectors to increase sales, exports, investment and jobs. Based on the findings of a study of twelve sectors in Serbia, the project has identified those sectors with the greatest potential to compete in international markets: ICT; tourism; film and production; construction services; auto parts; wood processing and furniture; and renewable energy.

The project is seeking to reinforce the competitiveness of these sectors through policy reforms, workforce development and communications efforts and undertakes both transactional and transformational activities to meet these objectives. Transactional activities include targeted sales and marketing efforts, e.g. trade shows, market research, B2B meetings and direct negotiations; while transformational activities seek to enhance the long-term competitiveness of a sector, e.g. supporting firms to attain international certifications and standards; building industry groups/associations to advocate on behalf of a sector; implementing workforce development initiatives that establish the required technical skills; and making international branding efforts to increase awareness of the benefits of investing in Serbia.

An example of how this project is helping the Serbian wood processing industry is in providing support to obtain Forest Stewardship Council Chain of Custody certification (FSC/COC), which tracks wood and timber fibre from the point of origin through the stages of the manufacturing process. The Competitiveness Project is facilitating the wood processing industry's use of sustainable resources and FSC Chain of Custody certifications in local furniture production. The project is serving as the $\mathrm{FSC} / \mathrm{COC}$ focal point in Serbia, and has helped sixteen wood processing manufacturers obtain this certification, thus supporting them in expanding their market reach. Prior to this initiative, only one firm in Serbia had this certificate.

\section{Conclusion}

Serbia is getting closer to membership of the EU and of the WTO and, as it does so, companies will face opportunities and challenges to view their businesses from the perspective of the competition and opportunities that the EU market offers with its half a billion customers. The business sector needs to be prepared to changes that the liberalisation of the market will bring and it needs to be modernised in order to increase 
its efficiency. The current crisis should, therefore, be used to create competitive companies and to strengthen their capacities.

Progress towards reform is insufficient and a more decisive implementation is needed. The major player in the new model of behaviour is the government. The government needs to review the effects of development programmes, as well as apply a plan for exiting the crisis. More investment is needed in tradable sectors, mostly in manufacturing industry and in exported services. We should now turn to the tradable goods sector which can strengthen exports and foreign trade exchange. It will be necessary to change the structure of investment; to invest more and spend less; to turn to exports rather than to imports; to finish the restructuring of the economy; and to continue education reforms. It also means that pushing investment into manufacturing and agriculture industry should be our main goal. Beneficiary programmes should also be used primarily in establishing joint ventures between our companies and foreign buyers.

\section{References}

Global Competitiveness Index 2010-2011 rankings and 2009-2010 comparisons www.weforum.org

Savić, Nebojša (2010) 'Kako unaprediti konkurentnost Srbije. Problematične institucije i infrastruktura' Ekonom:east 549, 27 November 2010.

Hardouvelis, Gikas A (2010) Univerzitet Pirej Grčka, Glavni ekonomista i direktor istraživačkog sektora, 5 October 2010. www.eurobank.gr/research

Vujović, S, S. Stevanović and D. Petrović (2010) 'Negative consequences of foreign direct investments - Experiences from different countries' Ekonomika poljoprivrede 57: Belgrade, April-June: 175-193.

Jakopin, Edvard and Jurij Bajec (2009) 'Challenges of Industrial Development of Serbia' Panoeconomicus 4: 507-525.

Đuričin, Dragan N, Stevo V. Janošević and Đorđe M. Kaličanin (2010) Menadžment $i$ strategija Ekonomski fakultet u Beogradu: Beograd.

Program podrske razvoju konkurentnosti MSPP u 2010. godini. www.nar.gov.rs. 